

\title{
Effect of kilning and milling on the dough-making properties of oat flour
}

Food Science and Technology = Lebensmittel-Wissenschaft und Technologie

Londono, D.M.; Smulders, M.J.M.; Visser, R.G.F.; Gilissen, L.J.W.J.; Hamer, R.J.

https://doi.org/10.1016/j.lwt.2015.04.033

This article is made publicly available in the institutional repository of Wageningen University and Research, under the terms of article $25 \mathrm{fa}$ of the Dutch Copyright Act, also known as the Amendment Taverne. This has been done with explicit consent by the author.

Article $25 \mathrm{fa}$ states that the author of a short scientific work funded either wholly or partially by Dutch public funds is entitled to make that work publicly available for no consideration following a reasonable period of time after the work was first published, provided that clear reference is made to the source of the first publication of the work.

This publication is distributed under The Association of Universities in the Netherlands (VSNU) 'Article 25fa implementation' project. In this project research outputs of researchers employed by Dutch Universities that comply with the legal requirements of Article $25 \mathrm{fa}$ of the Dutch Copyright Act are distributed online and free of cost or other barriers in institutional repositories. Research outputs are distributed six months after their first online publication in the original published version and with proper attribution to the source of the original publication.

You are permitted to download and use the publication for personal purposes. All rights remain with the author(s) and / or copyright owner(s) of this work. Any use of the publication or parts of it other than authorised under article $25 \mathrm{fa}$ of the Dutch Copyright act is prohibited. Wageningen University \& Research and the author(s) of this publication shall not be held responsible or liable for any damages resulting from your (re)use of this publication.

For questions regarding the public availability of this article please contact openscience.library@,wur.nl 


\title{
Effect of kilning and milling on the dough-making properties of oat flour
}

\author{
Diana M. Londono a, Marinus J.M. Smulders ${ }^{\text {a, c, * }}{ }^{*}$, Richard G.F. Visser ${ }^{\text {a }}$, \\ Luud J.W.J. Gilissen ${ }^{\text {b, c }}$, Rob J. Hamer ${ }^{\mathrm{d}}$ \\ a Wageningen UR Plant Breeding, Wageningen University and Research Centre, P. O. Box 386, NL-6700 AJ Wageningen, The Netherlands \\ ${ }^{\mathrm{b}}$ Bioscience, Wageningen University and Research Centre, P.O. Box 16, NL-6700 AA Wageningen, The Netherlands \\ ${ }^{c}$ Allergy Consortium Wageningen, P.O. Box 16, NL-6700 AA Wageningen, The Netherlands \\ ' Wageningen UR Food Chemistry, Wageningen University and Research Centre, P. O. Box 8129, NL-6700 EV Wageningen, The Netherlands
}

\section{A R T I C L E I N F O}

\section{Article history:}

Received 31 December 2014

Received in revised form

10 April 2015

Accepted 13 April 2015

Available online 22 April 2015

\section{Keywords:}

Oat flour

Oat bran

Oat dough

IR kilning

Steam kilning

\begin{abstract}
A B S T R A C T
Oats are mostly used for porridges, flakes, and cereal breakfast. The current oat kilning and milling methods are suited for these purposes. Bread-making applications have been explored, but the bread quality results are far from optimal. The goals of this study were to determine whether infrared (IR) and steam kilning may impact dough rheology, and to assess if particle size distribution and bran content could impact dough properties. IR kilning had a negative effect on the dough-making properties of oat grains, resulting in a very stiff and short dough, while steam-kilned dough did not change the doughmaking properties. Oat meal also resulted in a stiff and short dough, and re-milling did not change this pattern. In contrast, removing all the bran from the oat meal improved dough-making properties. Dough rheology was negatively impacted by the bran, and this effect was larger for large and medium size bran than for fine bran. This was attributed to their high content of beta-glucans. In conclusion, current kilning and milling methods are not suitable for bread-making purposes and these treatments must be optimized. Whole grain oat meal is not a proper material for bread applications in the absence of fractionation.
\end{abstract}

๑ 2015 Elsevier Ltd. All rights reserved.

\section{Introduction}

The most common uses of oats are related to porridges, flakes and meal, and the current technology is adapted to fit these uses. There is an increasing demand for gluten-free products and oats are considered an interesting alternative because it contains healthy compounds that can supplement the diet (Andon \& Anderson, 2008; Gilissen et al. 2012; Gilissen, Van der Meer, \& Smulders, 2014), and it has generally been accepted that celiac disease patients can consume oats without detrimental inflammation of the small intestine (Hardy et al., 2015; Janatuinen, Kemppainen, \& Julkunen, 2002; Kaukinen, Collin, Huhtala, \& Mäki, 2013; Londono et al. 2013; Pulido et al., 2009).

\footnotetext{
* Corresponding author. Wageningen UR Plant Breeding, P.O. Box 386, NL-6700 AJ Wageningen, The Netherlands. Tel.: +31 317480840.

E-mail addresses: dianalondono7@hotmail.com (D.M. Londono), rene. smulders@wur.nl (M.J.M. Smulders), richard.visser@wur.nl (R.G.F. Visser), luud. gilissen@wur.nl (L.J.W.J. Gilissen), rob.hamer@wur.nl (R.J. Hamer).
}

Kilning and milling are two important steps of oat processing that can influence the quality of the grains, affecting their potential use for new applications, e.g., bread-making. Oats contain high lipid and beta-glucan contents in comparison to other cereals, and these compounds represent a challenge during storage and food processing because they can have adverse effects on the sensory properties of grains and of end products. Oxidation of lipids can cause a rancid taste (Lehtinen \& Kaukovirta-Norja, 2011), while beta-glucans affect food texture and mouth feeling due to their high viscosity. Therefore, special attention should be given to storage and processing of oats in comparison to other cereals.

Lipid oxidation occurs through the action of lipase enzymes. Lipase activity in oats is exceptionally high (O'Connor, Perry, \& Harwood, 1992), which, in combination with the high lipid content, makes the stability of oat lipid a major challenge for the oatprocessing industry. Lipolysis produces a rancid taste, and it generally begins when the grains are milled, although it may also start after the dehulling (Peltonen-Sainio, Kontturi, Rajala, \& Kirkkari, 2004). The lipase activity is localized mainly in the bran 
fraction, thus pearling of the outer grain layers is an alternative to preserve the sensory quality of the starchy endosperm flour $(\mathrm{Hu}$, Wei, Ren, \& Zhao, 2009), although the endosperm also presents some activity that needs to be neutralized. The inactivation of lipases is known as kilning. In the kilning process the dehulled grains undergo a heat treatment in which the heat must reach the outer bran layers of the grains, where enzymes are most active, as well as the inner endosperm layers (Lehtinen, Kiiliäinen, Lehtomäki, \& Laakso, 2003). The heat treatment is also beneficial for the taste of oats (Klensporf \& Jeleń, 2008). The heat treatment can be performed dry or with steam (Head, Cenkowski, Arntfield, \& Henderson, 2011), the latter being the most popular. The higher water content makes steaming more effective in wiping out enzyme activity (Gates, Sontag-Strohm, Stoddard, Dobraszczyk, \& Salovaara, 2008). Recently some millers have adopted the infrared (IR) technology for dry kilning because it enables treating larger amounts of grains in a shorter time. Both methods are applied without taking into account the food application for which the grains are intended.

Milling takes place after kilning of the grains. The purpose of grain milling is to produce flour or meal. The most common oat material used for baking applications is whole grain oat meal, which includes the bran fraction and, consequently, the betaglucans that are mainly present in the bran. It has been shown that the viscosity of beta-glucans may impact negatively dough rheology when present at high concentrations (ca. $5 \mathrm{~g} / 100 \mathrm{~g}$, Londono, Gilissen, Visser, Smulders, \& Hamer, 2015). It is known that the texture of the resulting material (flour or meal) is important for bread applications, but also the composition (Londono et al. 2015).

Wheat is the most used cereal for bread applications. Wheat does not need kilning treatment for enzyme stabilization, only drying to lower the moisture level and allow long-term storage, but milling and fractionation are key processing factors that influence wheat baking quality. In wheat it is known that heating can destroy gluten-forming properties (Schofield, Bottomley, Timms, \& Booth, 1983), which may be due to sulfydryl groups being oxidized to disulfide bonds (Weegels, De Groot, Verhoek, \& Hamer, 1994). For oats, Gates, Dobraszczyk, Stoddard, Sontag-Strohm, and Salovaara (2008) found that mild steam treatments yielded softer oat groats, but it is unknown whether the current kilning and milling methods may impact negatively the dough making properties of the grains.

Here we studied whether the kilning methods currently used (steam and IR kilning) as well as milling and fractionation can affect the dough extensibility properties of oat grains. The results provide information for future standardization specifically for bread applications.

\section{Materials and methods}

\subsection{Materials}

We tested the effect of steam and IR kilning methods and of particle size distribution on dough extensibility properties of oat flour. For the kilning experiments we used oat grains from the husked cultivar Gigant, harvested in 2010 and provided by a commercial miller (De Halm, The Netherlands). The grains had been already dehulled by the miller and were stored at $4{ }^{\circ} \mathrm{C}$ before milling.

For the fractionation experiments we used commercial oat meal (De Vlijt, The Netherlands). It was stored at $4{ }^{\circ} \mathrm{C}$ until use. Vital gluten (Cargill, The Netherlands) and salt (Merck) were used to prepare the dough according to Londono, Smulders, Visser, Gilissen, and Hamer (2014). The composition (as is) of oat meal was $12.5 \mathrm{~g} /$ $100 \mathrm{~g}$ protein (determined using AACC Method 46-30.01; AACC
International. 2000), $5.54 \mathrm{~g} / 100 \mathrm{~g}$ beta-glucan (AACC Method 32-23.01), $62 \mathrm{~g} / 100 \mathrm{~g}$ starch (AACC Method 76-13.01), and $7 \mathrm{~g} /$ $100 \mathrm{~g}$ moisture.

\subsection{Kilning treatment}

The oat grains were treated following two procedures that are normally used to inactivate lipase activity: steam kilning and infrared (IR) kilning. Untreated grains were used as control. We did not test the efficiency of these methods to inactivate the enzyme, because both are used routinely and known to be effective to prevent lipid oxidation.

The steam kilning treatment was performed in a $0.5 \mathrm{~m}^{3}$ steel container as described by Londono et al. (2014). First, a grain layer of three $\mathrm{cm}(2 \mathrm{~kg})$ was placed in the container and steamed for $3 \mathrm{~min}$ at $100{ }^{\circ} \mathrm{C}$. Then, the grains were placed in a drying oven at $80{ }^{\circ} \mathrm{C}$ overnight for tempering.

The IR kilning was performed following the protocol used by the miller that provided the grains (De Halm, The Netherlands) in a custom-made IR device. First, the grains were placed in a Vibronet (Nebraska, USA) at 17-19 g/100 g moisture for $1 \mathrm{~h}$. Then, the grains were placed on a belt to be heated by eleven IR high-pressure burners (HOAF, The Netherlands) for about 15 s. Finally, the grains were stored in a tempering bunker for 15-20 min.

\subsection{Flours}

For the experiment about the effect of kilning on dough rheology, flour was prepared from the grains of cultivar Gigant by milling at $8000 \mathrm{rpm}$ using a laboratory pin mill (Hosokawa Alpine D-86199, Augsburg). The resulting material was fractionated using a series of sieves of $0.50,0.30$, and $0.25 \mathrm{~mm}$ mesh size that were placed on a Retch AS200 sieving machine for $10 \mathrm{~min}$. Only the fraction that passed through the $0.250 \mathrm{~mm}$ sieve was used for the experiments using the standard method developed by Londono et al. (2014). The moisture content of the IR kilned grains before milling was $9 \mathrm{~g} / 100 \mathrm{~g}$ and the moisture contents of steamed and untreated grains were 13 and $12 \mathrm{~g} / 100 \mathrm{~g}$, respectively. The moisture content of all the flours was about $11 \mathrm{~g} / 100 \mathrm{~g}$.

\subsection{Particle size distribution}

We used two approaches to study the effect of particle size distribution on dough properties of oat flour. In the first approach we re-milled commercial oat whole meal using a laboratory mill (Hosokawa Alpine D-86199, Augsburg) at maximum speed $(16,000 \mathrm{rpm})$, to reduce the particle size of the material. The particle size distribution was characterized by sieving the materials using a series of sieves of $0.50,0.30$, and $0.25 \mathrm{~mm}$ placed on a sieving machine (Retch AS200) for $10 \mathrm{~min}$. The particle size distribution of oat meal and re-milled oat meal is shown in Table 1.

In the second approach we fractionated the oat meal into bran and fine flour using a series of sieves $(0.50,0.30$, and $0.25 \mathrm{~mm})$. The particle size of the fine flour was $<0.25 \mathrm{~mm}$. This was used as the oat flour base for the experiments. Then, the bran fraction ( 0.50 and

Table 1

Particle size distribution of oat meal and re-milled oat meal.

\begin{tabular}{lll}
\hline Sieved fraction & Oat meal $^{\mathrm{a}}(\mathrm{g} / 100 \mathrm{~g})$ & Re-milled oat meal $^{\mathrm{b}}(\mathrm{g} / 100 \mathrm{~g})$ \\
\hline$>0.50 \mathrm{~mm}$ & 45 & 27 \\
$0.25-0.50 \mathrm{~mm}$ & 15 & 15 \\
$<0.25$ & 32 & 52 \\
Total recovered & 92 & 93 \\
\hline
\end{tabular}

a The particle size as it came from the shop.

b Re-milled at 16,000 rpm. 
$0.30 \mathrm{~mm}$ fractions) was re-milled at $16,000 \mathrm{rpm}$ and fractionated again using the same series of sieves into three fractions. These fractions were used to prepare mixtures based on $60 \mathrm{~g} / 100 \mathrm{~g}$ fine flour and $40 \mathrm{~g} / 100 \mathrm{~g}$ of each of the re-milled bran fractions. Fine flour was used as control. The contents of protein (AACC Method 46-30.01) and beta-glucan (AACC Method 32-23.01) of the remilled bran fractions were quantified. The composition of the bran fractions used in the mixtures is shown in Table 2.

\subsection{Dough preparation and extensibility test}

The dough for the extensibility test was prepared as described by Londono et al. (2013) using a Micro-Farinograph (Brabender instruments, Mod.-No. 8110, Germany) and a $10 \mathrm{~g}$ mixer head. Water was added to prepare a dough system containing gluten $(12.8 \mathrm{~g} / 100 \mathrm{~g})$ at a peak consistency of $850+/-20$ Brabender units (BU). The mixing time depended on the experimental conditions because the process of hydration to reach the desired consistency was slower in some treatments than in others. After mixing the dough was allowed to relax in a sealed plastic container within an incubator for $20 \mathrm{~min}$ at $30{ }^{\circ} \mathrm{C}$ and $85 \%$ relative humidity. Then the complete dough was moulded into a ball by hand and pressed between two oiled lubricated and grooved Teflon blocks to make dough strips. The strips were allowed to relax again for $40 \mathrm{~min}$ within the mould in a plastic container at $24{ }^{\circ} \mathrm{C}$ and $80 \%$ relative humidity. Subsequently, the dough strip was placed in its holder and maximum resistance to extension $(\mathrm{g})$ and extensibility at maximum resistance $(\mathrm{mm})$ and total extensibility $(\mathrm{mm})$ of each strip were measured using a Texture Analyser fitted with the SMS/ Kieffer Extensibility Rig (Stable Micro systems). The standard settings for wheat flour dough were used according to instructions of manufacturer. The test was performed in triplicate and about 7-9 measurements were taken per dough sample. The resulting graphs represent the average of 21-27 measurements.

Table 2

Protein and beta-glucan contents of the re-milled bran fractions used in the flour mixtures.

\begin{tabular}{lll}
\hline Fraction size & Protein $(\mathrm{g} / 100 \mathrm{~g})$ & Beta-glucans $(\mathrm{g} / 100 \mathrm{~g})$ \\
\hline Large $(>0.50 \mathrm{~mm})$ & 16.9 & 8.4 \\
Medium $(0.30-0.50 \mathrm{~mm})$ & 12.2 & 8.2 \\
Fine $(<0.25 \mathrm{~mm})$ & 10.2 & 1.6 \\
\hline
\end{tabular}

\section{Results}

\subsection{Effect of kilning on dough extensibility}

Steam kilning and IR kilning, commonly used to inactivate the lipase activity in oat grains, were compared to check if heating had an effect on the dough extensibility properties of oat flour using the standard dough system developed by Londono et al. (2014). Flour from untreated grains was used as a control. Kilning treatments affected the extensibility properties of oat flour. With steam kilning a similar Farinograph behavior was obtained as with untreated grains, although the kilning increased the amount of water needed to reach the peak consistency by $5 \%$. In contrast, IR kilning completely changed the Farinograph behavior of the dough: water absorption was increased by $34 \%$ and the time required to reach peak was increased from 2 to 5 min (Fig. 1).

Using the micro-extension rig the dough samples prepared in the Farinograph (at peak time) were tested. Again, the non-kilned and steam kilned dough showed similar behavior. The IR kilned oat gave a very stiff and short dough (Fig. 2).

\subsection{Effect of particle size distribution on dough extensibility}

We tested the effect of particle distribution on dough extensibility to determine whether composition was more relevant for dough rheology than particle size. This effect was assessed in two ways. First, we compared the Farinograph and extensibility behavior of normal oat whole meal, as bought in a shop, with the same oat whole meal but re-milled at 16,000 rpm. Second, we prepared mixes of the $0.25 \mathrm{~mm}$ flour fraction with re-milled bran varying in particle size $(<0.25,0.30-0.50$, and $>0.50 \mathrm{~mm})$ in proportions $60 \mathrm{~g} / 100 \mathrm{~g}$ fine flour and $40 \mathrm{~g} / 100 \mathrm{~g}$ re-milled bran. Fine flour without addition of bran was used as a control. We used the standard dough system developed by Londono et al. (2014).

The water absorption was affected by the re-milling process. Remilled oat meal needed $10 \%$ more water to reach the peak consistency. However, the Farinograph behavior of oat meal and re-milled oat meal was similar (Fig. 3). The extensibility properties of the dough of oat meal and re-milled oat meal were also similar (Fig. 4). This implies that changing the size distribution of the material did not affect rheology. The particle size distribution is presented in Table 1. In contrast, removing all the bran from the meal to prepare
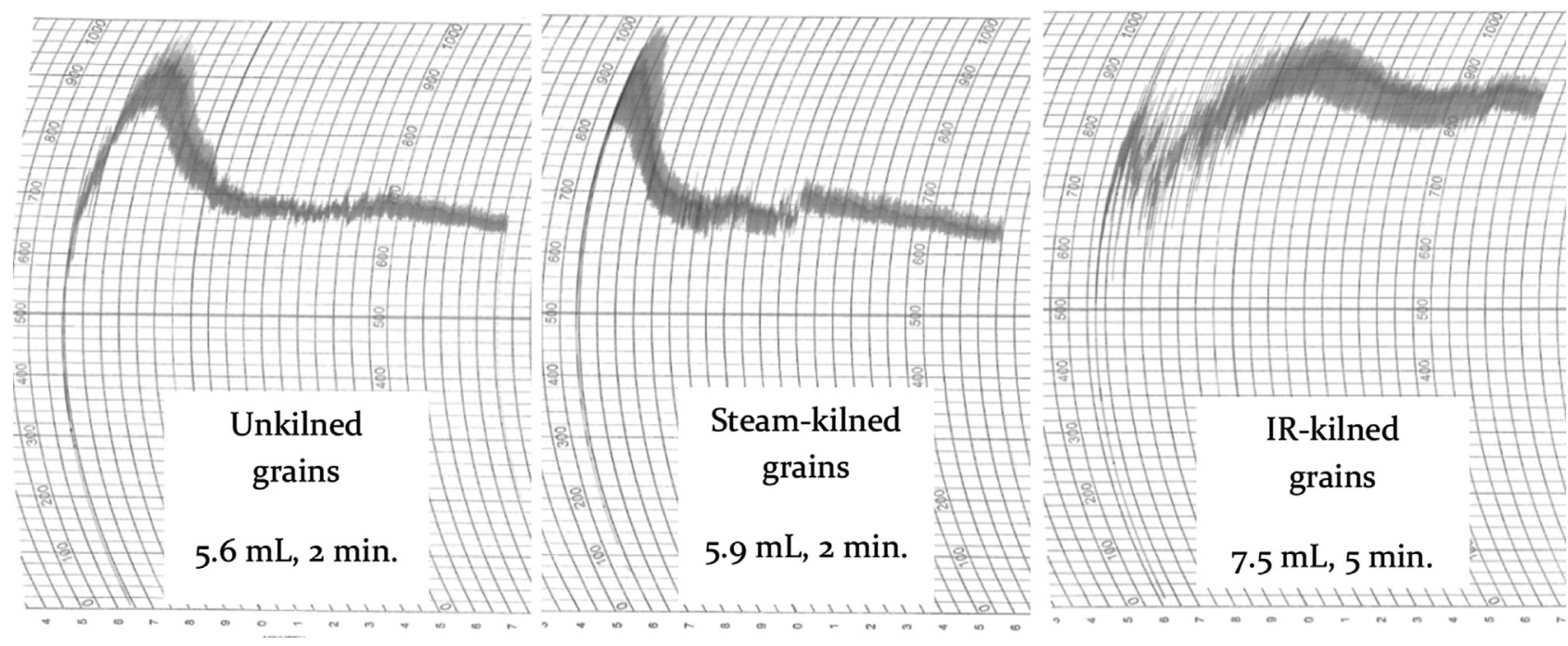

Fig. 1. Farinograms of oat flour made of untreated grains (left), steam-kilned grains (middle), and IR-kilned grains (right). 


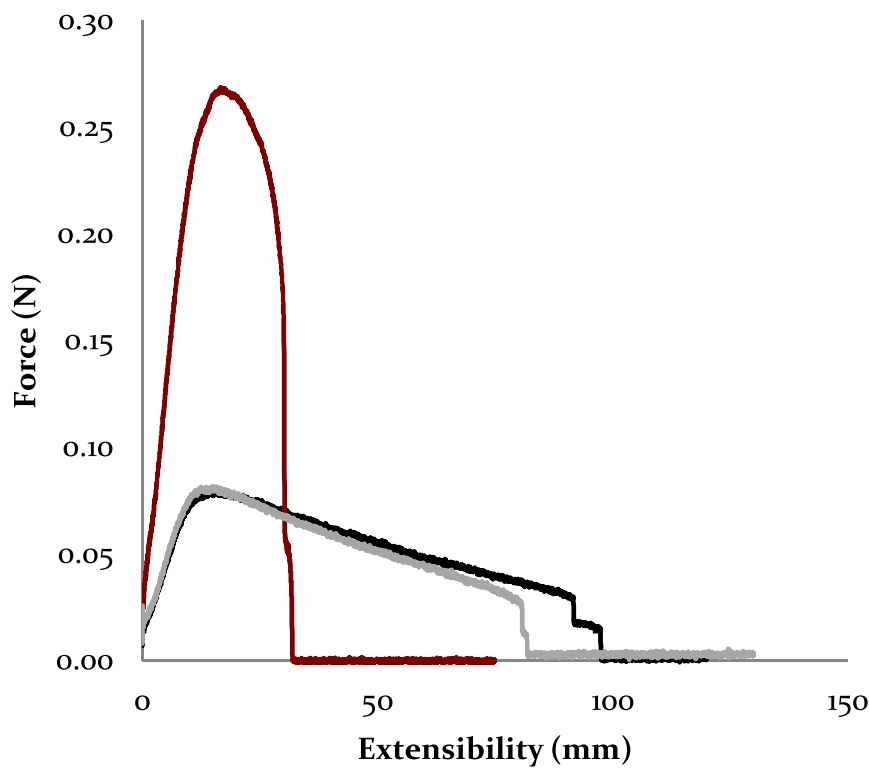

Fig. 2. Extensibility of oat dough made of non-kilned grains, IR-kilned grains, and steam-kilned grains. Black line: control (no kilning); grey line: steam kilning; red line: IR kilning (For interpretation of the references to colour in this figure legend, the reader is referred to the web version of this article.).

a dough with fine flour $(<0.25 \mathrm{~mm})$ resulted in a less stiff and much more extensible dough in comparison to oat meal (Fig. 4).

Replacement of $40 \mathrm{~g} / 100 \mathrm{~g}$ of fine flour with bran affected the water absorption and the Farinograph behavior of the flour. No difference was observed with addition of fine bran, while medium and large bran (Table 2 ) increased water absorption by $10 \%$ to reach the consistency of $850 \mathrm{BU}$, and the peak time from 2 to $4 \mathrm{~min}$ (Fig. 5). The dough extensibility of oat flour was impacted negatively by the addition of bran. Fine bran fraction had a smaller impact than the medium and large bran fractions (Fig. 6).

\section{Discussion}

As oat bread applications are being explored it is important to establish whether kilning and milling methods are also suitable for bread-making purposes. For that purpose we compared here two

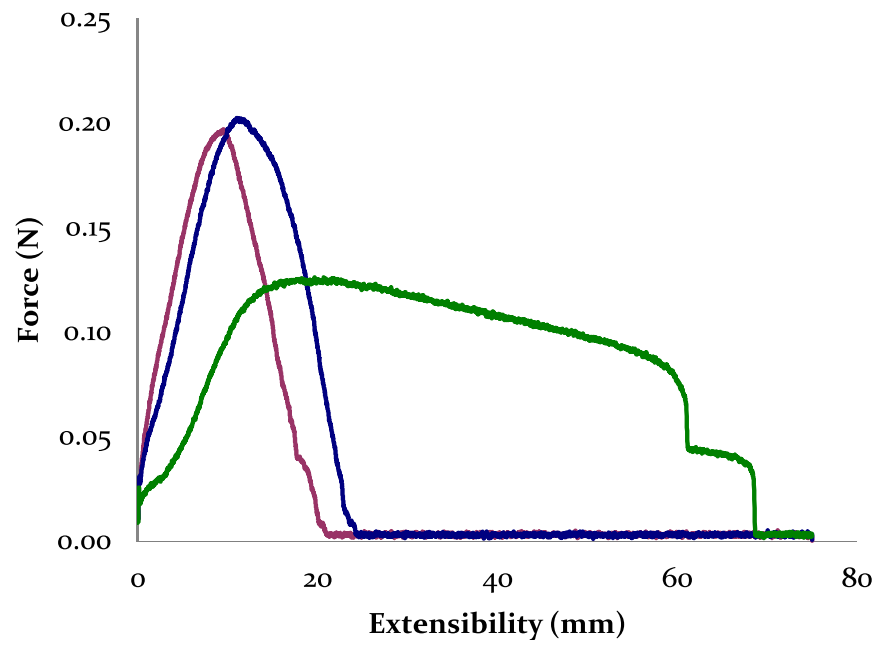

Fig. 4. Extensibility of dough made of oatmeal, re-milled oatmeal, and of the finest sieved fraction of oat meal $(<0.25 \mathrm{~mm})$. Pink line: oatmeal; blue line: re-milled oat meal; green line: fine oat flour (fraction $<0.25 \mathrm{~mm}$ ) (For interpretation of the references to colour in this figure legend, the reader is referred to the web version of this article.).

kilning methods, steam and infrared (IR) kilning, for effects on particle size distribution and on oat dough-making properties.

IR harmed the dough-making properties of oat flour completely. IR-kilned grains produced a very stiff and non-extensible dough (Fig. 2). This means that IR kilning is not suitable for bread applications as extensibility is an important characteristic related to bread quality. It is known that IR and steam kilning treatments can change the shape of starch granules and affect the protein network (Hu, Xing, \& Ren, 2010). The negative effect of IR kilning in oat grains might be comparable to the damage that heat causes to wheat grains, which also is characterized by a negative impact on gluten-forming properties (Schofield et al., 1983) and on baking quality (Ghaly \& Taylor, 1982). The purpose of the heat treatment in wheat grains is just decreasing moisture of avoid damage during storage (Bruce, 1992), but in oats the main purpose is to inactivate enzymes and thus to prevent lipid oxidation which would otherwise cause a rancid taste. Oats are also heat-treated to prevent developing a particular taste and aroma (Moltenberg, Magnus, Bjorge, \& Nilsson, 1986). According to our results, the steam
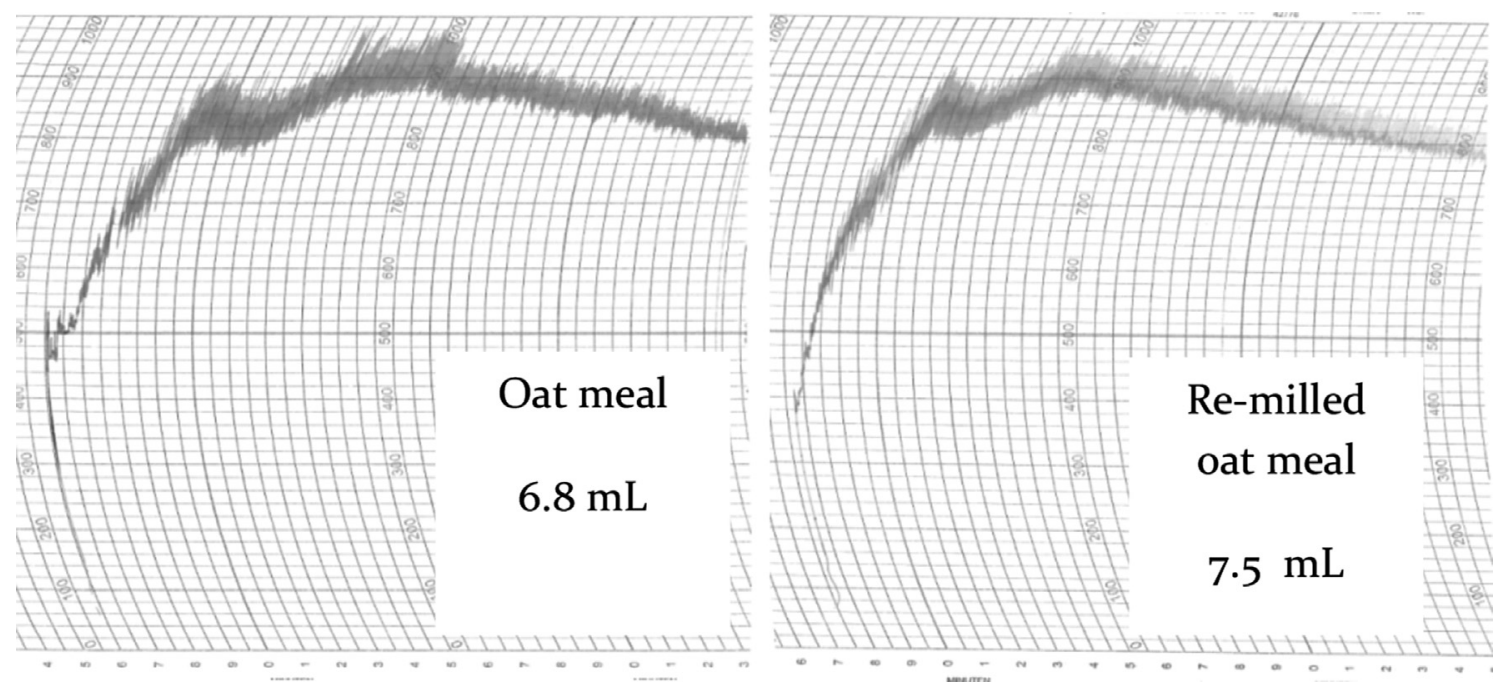

Fig. 3. Farinograph behavior of oat meal and re-milled oat meal. 


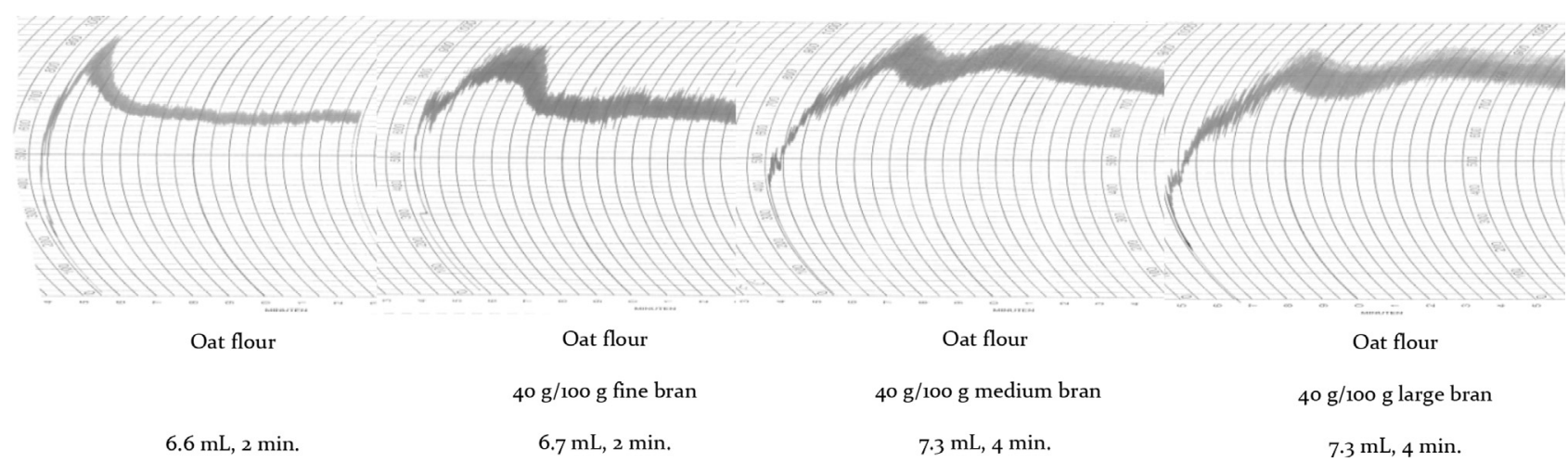

Fig. 5. Farinograph behavior of doughs made of oat flour $(<0.25 \mathrm{~mm})$ and of mixtures of $60 \mathrm{~g} / 100 \mathrm{~g}$ oat flour and $40 \mathrm{~g} / 100 \mathrm{~g}$ fine, medium and large bran.

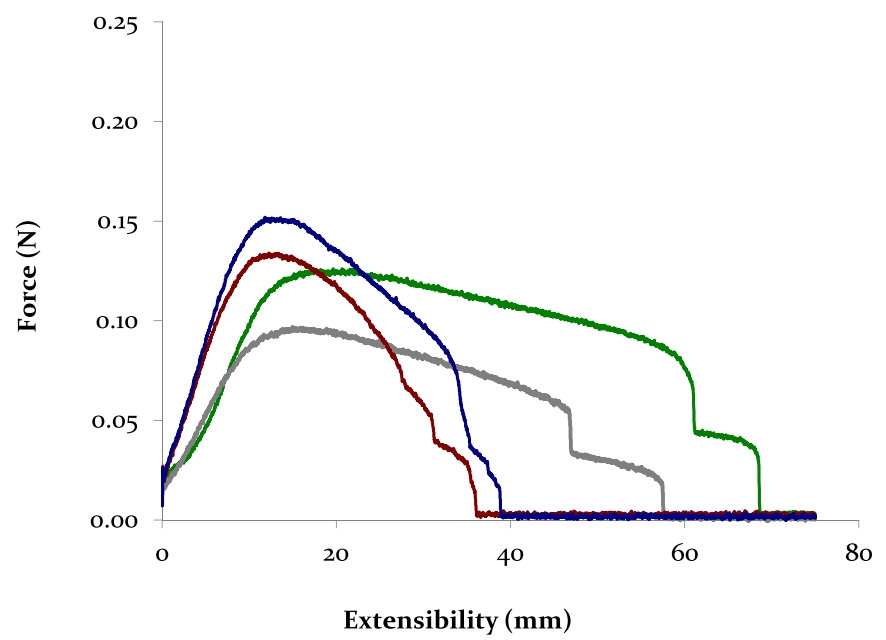

Fig. 6. Dough extensibility of fine oat flour $(<0.25 \mathrm{~mm})$ and of mixtures based on $60 \mathrm{~g} /$ $100 \mathrm{~g}$ fine flour and $40 \mathrm{~g} / 100 \mathrm{~g}$ bran particles of various sizes: fine $(<0.25 \mathrm{~mm})$, medium $(0.30-0.50 \mathrm{~mm})$, and large ( $>0.50 \mathrm{~mm})$. Green line: control (no bran); grey line: fine $(<0.25 \mathrm{~mm})$ bran; red line: medium $(0.30-0.50 \mathrm{~mm})$ bran; blue line: large $(>0.50 \mathrm{~mm})$ bran (For interpretation of the references to colour in this figure legend, the reader is referred to the web version of this article.).

kilning method used in this study would be appropriate for bread applications. However, more research is needed to standardize the process to establish the most suitable conditions to stabilize oat grains. Steam (hydrothermal) treatments to oats have also been reported as detrimental for dough rheology of composite wheatoat mixtures (Zhang, Moore, \& Doehlert, 1998). Finally, extrusion is an alternative technique to inactivate enzymes, as Lampi et al. (2015) recently reported that lipids in oat grains could be stabilized by extrusion even at a temperature of $70{ }^{\circ} \mathrm{C}$. However, as extrusion by itself is known to modify technological and nutritional properties of oats, the net effects on dough characteristics is currently not known.

Reducing the particle size of oat meal did not affect its doughmaking properties. Both doughs were stiff and short. In contrast, removing all the bran from the oat meal resulted in a more extensible and less stiff dough (Fig. 4). From this we can conclude that oat dough rheology is negatively impacted by the bran. This could be due to the large particle size of the bran as this may cause physical disruption of the protein network (Noort, van Haaster, Hemery, Schols, \& Hamer, 2010), or to the chemical composition of the bran (Wang, van Vliet, \& Hamer, 2004). Our results indicate that beta-glucans are the oat component responsible for the negative impact of bran on the rheology of our dough system. Betaglucans, which are mainly present in the bran fraction of oats, increase dough stiffness and reduce dough extensibility (Londono et al. 2015). There was no difference between adding high viscosity beta-glucans to oat flour at a concentration of $5 \mathrm{~g} / 100 \mathrm{~g}$ and using whole grain oat meal (which had a beta-glucan content of $5.5 \mathrm{~g} /$ $100 \mathrm{~g}$ ). Large and medium bran fractions affected dough properties in a larger extent than fine bran fraction (Fig. 6). This is probably related to the main difference among the bran fractions, which is their beta-glucan content: large and medium bran fractions contained ca. $8 \mathrm{~g} / 100 \mathrm{~g}$ beta-glucans, while fine bran fraction contained only $1.6 \mathrm{~g} / 100 \mathrm{~g}$ (Table 2). Wheat bran had also a detrimental effect on dough bread-making performance, but, in contrast to oat, fine bran was more harmful than large and medium size bran (Zhang \& Moore, 1999). Whole grain oat meal is not suitable for bread applications because of its high content of betaglucans. However, fractionation is an interesting alternative that would allow producing low beta-glucan oat flour for bread applications next to bran, which can be used to enrich other food products.

\section{Conclusion}

The current kilning and milling methods used to process oats are not suitable for bread applications. Our results showed that IR kilning harms completely the dough-making properties of oat grains, resulting in a very stiff and short dough. Steam kilning did not affect dough-making properties. Oat meal is not a proper material for bread applications because its high beta-glucan content interferes with dough rheology. Fractionation could be used to remove the large and medium bran fractions, which contained most of the beta-glucans.

\section{Acknowledgments}

This research was funded by the Celiac Disease Consortium (BSIK03009), an Innovative Cluster approved by the Netherlands Genomics Initiative and partially funded by the Dutch Government (BSIK03009) and by the Netherlands' Ministry of Economic Affairs (KB05-001-019, KB05-003-032, KB15-001-003 and KB15-001007).

\section{References}

AACC International. (2000). Approved methods of the American association of cereal chemists (11th ed.). St. Paul, MN: The Association. Methods 32-23.01 46-30.01, and 76-13.01 http://dx.doi.org/10.1094/AACCIntMethod-32-23.01 http://dx.doi.org/10.1094/AACCIntMethod-46-30.01 http://dx.doi.org/10.1094/ AACCIntMethod-76-13.01.

Andon, M., \& Anderson, J. (2008). The oatmeal-cholesterol connection: 10 years later. American Journal of Lifestyle Medicine, 2, 51-57. 
Bruce, D. M. (1992). A model of the effect of heated-air drying on the bread baking quality of wheat. Journal of Agricultural Engineering Research, 52, 53-76.

Gates, F. K., Dobraszczyk, B. J., Stoddard, F. L., Sontag-Strohm, T., \& Salovaara, H (2008). Interaction of heat-moisture conditions and physical properties in oat processing: I. Mechanical properties of steamed oat groats. Journal of Cereal Science, 47, 239-244. http://dx.doi.org/10.1016/j.jcs.2007.04.003.

Gates, F. K., Sontag-Strohm, T., Stoddard, F. L., Dobraszczyk, B. J., \& Salovaara, H. (2008). Interaction of heat-moisture conditions and physical properties in oat processing: II. Flake quality. Journal of Cereal Science, 48, 288-293. http:/ dx.doi.org/10.1016/j.jcs.2007.09.009.

Ghaly, T., \& Taylor, P. (1982). Quality effects of heat treatment of two wheat varieties. Journal of Agricultural Engineering Research, 27, 227-234.

Gilissen, L. J. W. J., Van den Broeck, H. C., Londono, D. M., Salentijn, E. M. J., Koning, F, van der Meer, I. M., \& Smulders, M. J. M. (2012). Food-related strategies towards reduction of gluten intolerance and gluten sensitivity. In P. Koehler (Ed.), Proceedings of the 25th meeting of the working group on prolamin analysis and toxicity (pp. 29-35). September 2011 in Fellbach, Germany http://www.wgpat. com/proceeding_25th.pdf.

Gilissen, L. J. W. J., Van der Meer, I. M., \& Smulders, M. J. M. (2014). Reducing the incidence of allergy and intolerance to cereals. Journal of Cereal Science, 59, 337-353. http://dx.doi.org/10.1016/j.jcs.2014.01.005.

Hardy, M. Y., Tye-Din, J. A., Stewart, J. A., Schmitz, F., Dudek, N. L., Hanchapola, I., et al. (2015). Ingestion of oats and barley in patients with celiac disease mobilizes cross-reactive $\mathrm{T}$ cells activated by avenin peptides and immunodominant hordein peptides. Journal of Autoimmunity, 56, 56-65. http:// dx.doi.org/10.1016/j.jaut.2014.10.003.

Head, D., Cenkowski, S., Arntfield, S., \& Henderson, K. (2011). Storage stability of oat groats processed commercially and with superheated steam. LWT - Food Science and Technology, 44, 261-268. http://dx.doi.org/10.1016/j.lwt.2010.05.022.

Hu, X, Wei, Y, Ren, C. \& Zhao, J. (2009). Relationship between kernel size and shape and lipase activity of naked oat before and after pearling treatment. Journal of the Science of Food and Agriculture, 89, 1424-1427.

Hu, X., Xing, X., \& Ren, C. (2010). The effects of steaming and roasting treatments on $\beta$-glucan, lipid and starch in the kernels of naked oat (Avena nuda). Journal of the Science of Food and Agriculture, 90, 690-695.

Janatuinen, E. K., Kemppainen, T. A., Julkunen, R. J. K., et al. (2002). No harm from five year ingestion of oats in coeliac disease. Gut, 50, 332-335.

Kaukinen, K., Collin, P., Huhtala, H., \& Mäki, M. (2013). Long-term consumption of oats in adult celiac disease patients. Nutrients, 5, 4380-4389. http://dx.doi.org/ 10.3390/nu5114380.

Klensporf, D., \& Jeleń, H. H. (2008). Effect of heat treatment on the flavor of oat flakes. Journal of Cereal Science, 48, 656-661. http://dx.doi.org/10.1016/ j.jcs.2008.02.005.

Lampi, A.-M., Damerau, A., Li, J., Moisio, T., Partanen, R., Forssell, P., et al. (2015). Changes in lipids and volatile compounds of oat flours and extrudates during processing and storage. Journal of Cereal Science, 62, 102-109. http://dx.doi.org/ 10.1016/j.jcs.2014.12.011
Lehtinen, P., \& Kaukovirta-Norja, A. (2011). Oat lipids, enzymes, and quality. In E. H. Webster, \& P. Wood (Eds.), Oats chemistry and technology. AACC International. Lehtinen, P., Kiiliäinen, K., Lehtomäki, I., \& Laakso, S. (2003). Effect of heat treatment on lipid stability in processed oats. Journal of Cereal Science, 37, 215-221. http:// dx.doi.org/10.1006/jcrs.2002.0496.

Londono, D. M., Gilissen, L. J. W. J., Visser, R. G. F., Smulders, M. J. M., \& Hamer, R. J (2015). Understanding the role of oat $\beta$-glucan in oat-based dough systems. Journal of Cereal Science, 62, 1-7. http://dx.doi.org/10.1016/j.jcs.2014.12.003.

Londono, D. M., Smulders, M. J. M., Visser, R. G. F., Gilissen, L. J. W. J., \& Hamer, R. J. (2014). Development of a standard test for dough-making properties of oat cultivars. Journal of Cereal Science, 59, 56-61. http://dx.doi.org/10.1016/ j.jcs.2013.10.007.

Londono, D. M. Van't Westende, W. P. C., Goryunova, S. V., Salentijn, E. M. J., Van den Broeck, H. C., Van der Meer, I. M., et al. (2013). Avenin diversity analysis of the genus Avena (oat). Relevance for people with celiac disease. Journal of Cereal Science, 58, 170-177. http://dx.doi.org/10.1016/j.jcs.2013.03.017.

Moltenberg, E. L., Magnus, E. M., Bjorge, J. M., \& Nilsson, A. (1986). Sensory and chemical studies of lipid oxidation in raw and heat treated oat flours. Cereal Chemistry, 73, 579-587.

Noort, M. W. J., van Haaster, D., Hemery, Y., Schols, H. A., \& Hamer, R. J. (2010). The effect of particle size of wheat bran fractions on bread quality - evidence for fibre-protein interactions. Journal of Cereal Science, 52, 59-64.

O'Connor, J., Perry, H., \& Harwood, J. (1992). A comparison of lipase activity in various cereal grains. Journal of Cereal Science, 16, 153-163.

Peltonen-Sainio, P., Kontturi, M., Rajala, A., \& Kirkkari, A.-M. (2004). Impact dehulling oat grain to improve quality of on-farm produced feed. I. Hullability and associated changes in nutritive value and energy content. Agricultural and Food Science, 13, 18-28.

Pulido, O., Gillespie, Z., Zarkadas, M., Dubois, S., Vavasour, E., Rashid, M., et al. (2009). Introduction of oats in the diet of individuals with celiac disease: a systematic review. In Advances in food and nutrition research (Vol. 57)Elsevier Inc.

Schofield, J. D., Bottomley, R. C., Timms, M. F., \& Booth, M. R. (1983). The effect of heat on wheat gluten and the involvement of sulphydryl-disulphide interchange reactions, Journal of Cereal Science, 1, 241-253.

Wang, M., van Vliet, T., \& Hamer, R. J. (2004). How gluten properties are affected by pentosans. Journal of Cereal Science, 39, 395-402.

Weegels, P. L., De Groot, A. M. G., Verhoek, J. A., \& Hamer, R. J. (1994). Effects on gluten of heating at different moisture contents. II. Changes in physico-chemical properties and secondary structure. Journal of Cereal Science, 19, 39-47.

Zhang, D., \& Moore, W. R. (1999). Wheat bran particle size effects on bread baking performance and quality. Journal of the Science of Food and Agriculture, 79, 805-809.

Zhang, D., Moore, W., \& Doehlert, D. (1998). Effects of oat grain hydrothermal treatments on wheat-flour dough properties and breadbaking quality. Cereal Chemistry, 75, 602-605. 